\title{
Tek-Gungu
}

\section{Wartime Sexual Violence in Northern Uganda}

Once referred to as "the biggest forgotten, neglected humanitarian emergency in the world" by Jan Egeland, UN undersecretary-general for humanitarian affairs and emergency relief coordinator at that time, the northern Ugandan conflict between the Lord's Resistance Army (LRA) rebel group and the government of Uganda (GoU) between 1986 and 2006/2008 has received substantial international and academic attention. ${ }^{1}$ The LRA's horrendous atrocities in particular have been subjected to extensive scholarly debate. Multiple human rights violations committed by the Ugandan government armed forces, on the other hand, have received significantly less attention. Within this context, crimes of sexual violence against men perpetrated by the government's National Resistance Army (NRA) in the early years of the conflict, between the late 1980s and early 1990s, are particularly poorly documented and remain almost entirely absent from academic analyses of the conflict, with only few noteworthy exceptions. ${ }^{2}$ Although important scholarly and advocacy work by Chris Dolan and the Refugee Law Project (RLP) brought attention to these crimes in northern Uganda, arguably no systematic and comprehensive scholarly examination of male-directed sexual violence in this context exists to date.

Against this backdrop, this chapter sets out to paint a detailed picture of the dynamics surrounding conflict-related sexual violence against men in northern Uganda situated within their overall sociopolitical historical context and through a survivor's lens. Drawing on field research findings, I argue that sexual crimes against men, and specifically male rape, perpetrated by the NRA were widespread and part of wider systematic military operations against the Acholi population. By moving government-perpetrated crimes of sexual violence against men into the spotlight, the chapter thus offers a corrective to the predominant ways in which responsibilities for conflict-related human rights violations during the conflict in northern Uganda are typically allocated and distributed. 
Before proceeding with the analysis, however, a brief methodological and source-critical note from a postcolonial perspective is required. While the northern Ugandan conflict is extensively researched and documented, the most widely cited studies are primarily written from an outside perspective and tend to privilege the viewpoints of external, Western academics over national Ugandan scholars. These dynamics mirror many of the previously detected problems of "white man's" scholarship in international relations and conflict studies (Lake 2016; Fanon 1963). In an attempt to counter this neocolonial "whitewashing" of scholarship on politics and conflicts in Uganda, I deliberately seek to combine Ugandan scholars with Western authors as much as possible.

\section{HISTORICAL ROOTS OF THE CONFLICT}

The historical origins of the conflict between the LRA and the Ugandan government can be traced back to colonial times, and to some extent the conflict's roots lie in Uganda's overarching and deeply rooted ethnic divides (Kasozi 1994). During colonial occupation (1894-1962), alleged tribal differences between Ugandans from the north and the south resulted in binary categorizations and a regional as well as ethnicized two-level classification: The British colonial administration recruited northerners primarily for the military, in part because of their physical appearances and stereotypical assumptions of northerners as warriors (Onyango-Odongo and Jamal Mikla 1976), and southerners mostly for the civil service and the economy because of their presumed intellectual superiority. The country's south consequentially hosted the majority of Uganda's educated class, whereas the north became poor and underdeveloped. Dolan (2009) argues that this north-south divide and the singling out of men from northern Uganda into the military "contributed to a reputation for militarism and violence" (202) specifically for the Acholis, one of the largest tribes in the country's northern region. ${ }^{3}$ This reputation was simultaneously rooted in and further contributed to internalized ethnocentrism and racism and sat uneasily with Acholi men's self-perception.

The colonial administration's divide-and-rule policy consequently created a socioeconomic division between the north and south, generating a polarized nation ripe for conflict (Mamdani 1995). For decades this division was further intensified and exploited by (masculine) individual presidents who employed violence to rally one region against the other in order to catapult themselves into power and maintain their regime, generating a highly masculinized political climate marked by militarization and violence. Uganda's postcolonial history from 1962 onward is thus characterized by militarization and episodes of violence and counterviolence. Since colonial rule and after independence, the Ugandan state increasingly became a militarized instrument of violent retaliation. Anthropologist Heike Behrend (1999: 23) observes that "whoever took over state power was 
not only able to gain wealth, but also to take revenge-against members of other ethnic groups or religions" or populations of specific regions.

Following independence in 1962, Uganda experienced several exchanges of power. As Uganda's first postcolonial president, Milton Obote from the northern subregion of Lango continued to pit the country's regions against each other. Under his regime, northerners from Lango and Acholiland continued to be recruited into the armed forces. Obote's reign ended in 1971 with a military coup led by Colonel Idi Amin, from the West Nile region, who instituted a regime notorious for its political violence. One of Amin's first systematic violent acts upon acquiring political power was murdering numerous Acholi and Langi soldiers in the army. Following a violent regime toppled by an invasion from Tanzania, Amin was overthrown in 1979, with Milton Obote returning to power for a second regime. During the Obote II period, between 1979 and 1985, northerners once again dominated the armed forces.

Various political actors who already opposed Amin, including Yoweri Museveni, did not accept Obote's recapture of power. With his National Resistance Army (NRA), and alongside various other armed rebellions, Museveni waged a guerrilla campaign against the northern-led government and its Uganda National Liberation Army (UNLA). Museveni enjoyed immense support from his own region in the southwest, where a widespread antipathy prevailed toward what was perceived as (military and political) northern domination at the time. During this brutal civil war between 1980 and 1986, Acholi and Langi men mostly fought on the side of the UNLA government army under the ultimate command of Milton Obote. Eventually, rivalries and tensions within the UNLA-where Obote was accused of sacrificing Acholi soldiers in battle while protecting his Langi clansmen-resulted in a coup that installed Tito Okello from Acholiland as interim president. Fighting between the UNLA under Okello's command and Museveni's NRA continued, and despite a peace agreement between the two factions signed in Nairobi in December 1985, the NRA marched on Kampala. Up to this day, Museveni's violation of the 1985 Nairobi Peace Agreement is a source of deep-seated grievances among many Acholi and is interpreted as demonstrating that Museveni can never be trusted and does not want peace or reconciliation. In a turn of events over the following weeks, President Museveni effectively assumed presidential authority on 26 January 1986 and remains in power today-more than thirty-three years later.

Within the context of these pre-1986 episodes of violence and conflict, Acholi men in the state army were heavily involved in fighting Museveni's guerrilla movement, which was mostly composed of soldiers from the country's central, southern, and western regions and from Rwanda. Most of the fighting was concentrated in central Uganda, in particular around the town of Luwero, about an hour's drive north of Kampala. Across the Luwero triangle, "appalling atrocities were perpetrated by what was officially the national army, the UNLA" (Allen 
1991: 371), primarily composed of Acholi soldiers, who are reported to have killed an estimated three hundred thousand civilians. These historical developments are fundamentally important for situating and contextualizing cycles of violence and conflict within Acholiland following the NRA's acquisition of power (Otunnu 2002).

\section{Early Conflict Years-Retaliation and Intimidation}

As soon as Museveni and the NRA gained control over Uganda, thousands of Acholi (and Langi) fighters under the previous government(s) were forced to flee northward and seek protection in northern Uganda and southern Sudan. With growing unease about their complicated reintegration into civilian life and in opposition to the widespread violence perpetrated by NRA soldiers against the civilian population, substantial numbers of Acholi men soon joined the resistance movement. This armed opposition was primarily organized around the Uganda People's Democratic Army (UPDA), composed of former UNLA soldiers and formed in Juba, South Sudan, in March 1986.

Equipped with military and state power and thus with greater opportunity to commit acts of revenge against the northern population for previous crimes, NRA soldiers quickly advanced into northern Uganda. Various local and academic sources suggest that the NRA effectively took control of Gulu and Kitgum, the two largest towns in the region, in March 1986. The atmosphere during those first months was reported to have been largely calm, but it quickly changed as of May 1986, when the UPDA regrouped and attacked various NRA army barracks and outposts. Consequently, "stories of harassment and abuse of civilians by the NRA began circulating in mid 1986" (Branch 2010: 33). According to Adam Branch, "The paradoxical result would be that the NRA/M's wrong-headed strategy, in particular its violence against Acholi civilians, would give birth to the very rebellion the NRA/M had expected" (2010: 34).

During this time of political instability - a continuum of conflict and a spatial shift of violence from central to northern Uganda - spirit mediums began to play a significant role in relation to the conflict. As Allen and Vlassenroot (2010) observe, "Partly as a consequence of dramatic social changes, local understandings about communication with the spirit world had expanded in ways that helped make sense of what was happening" (7-8). Spirit mediums were particularly central to the LRA and the Holy Spirit Movement (HSM), led by a young woman called Alice Auma, popularly known as Alice Lakwena. In a complex chain of events, Alice was said to be possessed by various spirits, including one referred to as Lakwena-Acholi for "the messenger." "Initially formed as an egalitarian, genderequal, non-violent religious movement" (Finnström 2003: 109), the HSM expanded rapidly, with the political intention of overthrowing Museveni's government. The military wing of the movement, the Holy Spirit Mobile Forces (HSFM), regularly engaged NRA battalions in combat and registered various military advancements, 
moving approximately one hundred kilometers east of Kampala, where in November 1987 Alice's army was defeated.

Following Lakwena's defeat, Joseph Kony soon assumed control over Alice's remaining and returning soldiers, as well as over other former UNLA cadres. Kony eventually "renamed his army the Lord's Resistance Army (LRA) and continued to fight against the government" (Esuruku 2012: 147). Kony, who is often reported to be a cousin of Alice, similarly claims to have taken over some of her spirits, including the Lakwena, and to be possessed by various other spirits. Divides within the UPDA over the political and military direction of the armed resistance led various soldiers to turn toward Kony, whose movement grew in size and importance. As noted by Allen and Vlassenroot (2010), "By 1990, Kony's force was the only significant armed unit still fighting in the Acholi homelands" (10) against the NRA and eventually against the Acholi civilian population.

Interpreting the existence of these multiple rebel groups as the ultimate proof of Acholi resistance against Museveni's government, the state's armed forces soon unleashed a violent military campaign against the population, including the codenamed "Operation Pacifying North." For many observers, the NRA military operations must be seen as "part of a broader strategy implemented by the Government to target the Acholi population of northern Uganda for their links to the LRA and other rebel movements" (JRP 2013: 26) and for their alleged role in central Uganda in the 1980s. Various sources suggest that the NRA's violence occurred on the basis of accused rebel collaboration and as retaliation for previous crimes committed by Acholi soldiers against civilians in central Uganda, and in particular in the Luwero triangle region.

As summarized by a local cultural leader whom I interviewed in 2016, the NRA's "atrocities were also a payback and a revenge for what the Acholi soldiers did in Luwero, and they were a general punishment for all of Acholi." It is indeed a widely held belief, if not a conviction, among the Acholi population and among academic observers that NRA soldiers "exploited the opportunity to avenge themselves upon their former [Acholi] opponents by plundering, murdering, torturing and raping" (Behrend 1999: 25). Especially while searching for weapons taken by former UNLA soldiers and while tracing suspected and accused rebels or collaborators, NRA soldiers repeatedly attacked the Acholi civilian population. Men were particularly targeted by many (albeit not all) forms of violence, influenced by stereotypical assumptions associated with masculinity, violence, and aggression, and because of the common ethnocentric view of Acholi men as warriors. One community member commented that "the NRA thought that they will have to attack men because they thought that men are always the ones fighting and joining the rebels, especially the Acholi." It is within this context that soldiers of the NRA committed horrendous human rights abuses against the civilian population, including killings, torture, and sexual violence against women and men. 


\section{The LRA Conflict and Violence against Civilians}

While the early years of the conflict were primarily characterized by the NRA's large-scale human rights violations against civilian communities, the Acholi population arguably suffered most heavily at the hands of the LRA during subsequent years and during most of the conflict-affected period. Nevertheless, during this early phase of the war, the Ugandan army continued to commit human rights abuses, such as sexual and gender-based violence, primarily against women, and attacks against suspected or accused LRA collaborators or former rebels. With regard to the rebels, however, throughout the course of the conflict, levels of violence by the LRA varied significantly. Indeed, the rebels' acute brutality fluctuated over the years before ultimately increasing again. Violent attacks, massacres, and mass abductions were often in response to military operations instigated by the Ugandan government, such as Operation Pacifying North (1991), Operation Iron Fist (2002), and Operation Lightning Thunder (2008). Overall, for more than two decades, between 1986 and 2006/2008, the conflict between the LRA and the government resulted in large-scale human rights violations with immense civilian casualties. An African proverb quite adequately describes this situation of civilians being affected by and trapped between warring parties: "When two elephants fight, it is the grass that suffers."

While much has been written about the LRA's initial motivations for taking up arms against the government, many studies seem to exclusively suggest religious reasons, often mystifying, demonizing, and depoliticizing the rebel group, as previously observed and critiqued by Finnström (2010). In fact, most analyses of the conflict center around religious and spiritual aspects, concentrating on the LRA's motivation to rule Uganda in accordance with the Ten Commandments, as well as the LRA's widespread (and often seemingly random) brutality, while the rebel group's extant political ambitions are often ignored. However, throughout the course of the conflict, and particularly in the early years, the LRA justified their actions by clearly stating their political objectives, which included overthrowing the government under President Museveni and ensuring the Acholis' political participation and overall development. The armed opposition against the incumbent government was thereby also largely connected to a somehow spiritual mission to "cleanse" the Acholi tribe.

As the conflict gradually unfolded, however, attacks against the civilian population increased, in part as retaliation for not supporting the insurgency or for allegedly assisting the enemy-the Ugandan government. For instance, parts of the civilian population formed citizen militias and local defense units (LDUs), locally referred to as arrow boys, which the LRA interpreted as a sign of civilian resistance against their rebellion. At the same time, the LRA grew largely dependent upon forcefully abducting civilians, especially youths, to generate a larger armed force to fight its cause. This tactic became particularly acute during the 
mid-199os, when the LRA received significant support from the Sudanese government and was therefore able to expand their operations. According to UNICEF, approximately thirty-five thousand to sixty-six thousand children and youths were abducted by the LRA, forced to fight as child soldiers and/or serve as sex slaves. Data regarding scale and incidence of abduction, however, vary. Another widely quoted UNICEF figure refers to twenty thousand to twenty-five thousand abducted children. ${ }^{4}$ Overall, during the more than two-decade-long conflict, tens of thousands civilians were killed, mutilated, tortured, raped, and otherwise sexually abused by both the LRA and government forces. Most of the region's basic infrastructure was destroyed, and social relations largely broke down.

At the height of the conflict in the early 200os, more than one and a half million people, or up to 95 percent of the civilian population, were forced from their villages and homesteads into camps for internally displaced persons (IDPs) across the entire northern region. In these camps, civilians were supposed to live under the government's protection. In fact, however, the conditions in the camps were largely inhumane and IDPs suffered continuous human rights violations, including gender-based violence, often at the hands of the soldiers there to protect them. Civilians in the camps were similarly exposed and vulnerable to constant rebel attacks. Against this background, Chris Dolan (2009) appropriately describes the camps as a form of "social torture."

Throughout the course of the conflict, various political actors pursued different military and political attempts to put an end to the fighting, including military operations, mediations and negotiations, and an amnesty policy. Religious leaders and civil society representatives have also long been involved in attempting to find a mutual, peaceful end to the conflict, and therefore-often with support of the international community and regional stakeholders-initiated various rounds of peace talks and negotiations. Esuruku (2011) interestingly notes that although they were male dominated, these peaceful means were often regarded as feminine and incompatible with masculine ideas of resolving disputes militarily. Out of all the nonviolent means of conflict resolution and different attempts at negotiation, the 2006-2008 Juba peace talks were seemingly the most promising initiative. The talks led to the signing of various separate agenda items of a peace deal, although the final peace agreement was never signed by Joseph Kony and the LRA. The separately signed agenda items nevertheless provided a framework for a ceasefire deal, an Agreement on Accountability and Reconciliation (AAR), and an accord on Demobilization, Demilitarization, and Reintegration (DDR). The AAR eventually led to the development of a draft national transitional justice police, which forms the backdrop of the country's current attempts to deal with the past (see chapter 6).

Shortly after the signing of the AAR in February 2008, the Ugandan government set up a Transitional Justice Working Group with the aim of putting in place a concise policy of dealing with past atrocities. Essentially these 
developments provided the framework for Uganda's draft national transitional justice policy. Over the years, the drafting process has continually been delayed, largely attributable to an apparent lack of political will by the Ugandan government to initiate a holistic transitional justice approach. At the same time, the development of the transitional justice policy is heavily dependent upon external donor funds, much of which have been withdrawn in recent years. Under the auspices of the Justice Law and Order Sector (JLOS) of the Ugandan Ministry of Justice, the transitional justice policy sets out to provide "an overreaching framework of the Government of Uganda, designed to address justice, accountability and reconciliation needs of post conflict Uganda" (JLOS 2017: 3). Aimed "to ensure accountability, serve justice and achieve reconciliation" (ibid.), the policy proposes the implementation and utilization of the following: formal justice processes at the national and domestic level (the International Crimes Division [ICD] of the High Court of Uganda) and at the international level (the ICC); traditional justice processes; a truth-telling process; a reparations program; and an amnesty policy.

Prior to these developments, in late 2003, during a press conference with President Museveni and the ICC prosecutor at that time, Luis Moreno Ocampo, the government of Uganda announced the referral of the northern Ugandan situation to the ICC in The Hague. The court in 2005 issued five arrest warrants against the top LRA cadre, including its leader, Joseph Kony, and commander Dominic Ongwen, who in early 2015 surrendered and whose trial commenced in December 2016. ${ }^{5}$ The ICC indictments in the Ugandan situation sparked much scholarly debate and political concerns and are illustrative for wider debates about peace versus justice in conflict-affected and transitional settings. ${ }^{6}$ At the same time, the ICC faced much criticism for issuing arrest warrants only against LRA commanders, while failing to investigate crimes committed by NRA soldiers and instead heavily relying on support, intelligence, and information provided by the government.

By and large, Uganda therefore constitutes a poignant example of a relatively diverse transitional justice landscape, including international criminal proceedings by the ICC, national prosecutions by the ICD, traditional justice processes, and proposals for a state-driven and government-led draft national transitional justice policy. In chapter $6 \mathrm{I}$ discuss to what extent and how these transitional justice mechanisms imply the potential to respond to male sexual and gendered harms. In brief, the analysis shows that all of these measures are characterized by various sociopolitical as well as gendered blind spots and are thus largely unresponsive to the experiences, needs, and priorities of large portions of the conflictaffected population in general and of male sexual violence survivors in particular.

In today's postconflict context, reports about the current status, activities, and whereabouts of the LRA vary but generally indicate that the group operates with limited human capital, mostly in the Darfur region of Sudan, parts of the Central African Republic, and the Democratic Republic of the Congo. Joseph Kony is still 
at large, reported to be in hiding in the Central African Republic or Darfur, and recent evidence shows that the group has fewer than a hundred fighters, many of whom were recently abducted, with only few Acholi soldiers left.

\section{TEK-GUNGU-MALE RAPE IN NORTHERN UGANDA}

During the early stages of the war, the government's National Resistance Army also perpetrated crimes of sexual violence against men, and in particular penetrative rape. These crimes were widespread and constituted integral components of a wider military campaign centered around interrogation, retaliation, and punishment of the Acholi population at large.

The vast majority of male-directed sexual violence in northern Uganda took place between the late 1980 s and early 1990 s in the context of military operations perpetrated by the NRA, composed of soldiers from mostly southern and central Uganda. 7 Although the NRA, and later the UPDF, continued to commit atrocities across Acholiland throughout the entire conflict period, the military operations against the Acholi population predominantly ceased by the early 1990s, and with it came an end to the widespread perpetration of sexual violence against male (and female) civilians at the hands of the government forces. Crimes of sexual violence against men within this context were also accompanied by other human rights violations, such as acts of torture, beatings, or degrading and heinous crimeswhich included acts of defecating in cooking pots and granaries, and acts of urinating in the mouths of goats and cattle, perceived to be intended to humiliate the Acholi population-as well as sexual violence against women. As noted in the introduction, male rape in Acholiland is locally referred to as tek-gungu, which in Acholi language literally translates as "to bend over" (gungu) "forcefully" or "hard" (tek), or alternatively "the way that is hard to bend." According to my findings, this terminology specifically applies to male rape in this context and was not commonly used before.

Despite its prevalence, however, previous research on the war in northern Ugandan, although rich and diverse, has not yet sufficiently analyzed NRA-perpetrated violence in general, and definitely not sexual violence against men. Throughout the scholarship on the conflict, despite a few noteworthy exceptions, only occasional references to male-directed sexual violence exist, often lacking detailed information and analytical depth. For instance, Behrend's (1999) insightful account of the early years of the conflict only briefly refers to "the NRA's homosexual practices" of raping men (183). Finnström's (2009) extensive ethnographic research in the region likewise includes two brief cross-references to male rape, while demonstrating that up until recently, stories about tek-gungu only circulated as rumors across Acholiland. Dolan's groundbreaking research and influential advocacy work by the Refugee Law Project (RLP) and the Justice and Reconciliation Project (JRP) remain the only exceptions that go beyond solely mentioning 
male rape. Nevertheless, a holistic picture of sexual violence against men in Acholiland, including a deconstructed understanding of scope and prevalence as well as survivors' experiences, so far remains absent from the literature.

\section{Prevalence and Dynamics of Tek-Gungu}

In determining the scope and dynamics of sexual violence against men in northern Uganda, I rely on the qualitative empirical data underpinning this study, infused with secondary sources and literature where appropriate. Across time and space, determining the prevalence and scope of sexual violence during armed conflicts proves inherently difficult, conditioned by a general absence of numerical data, underreporting, and misrecognition (see chapter 2). Yet drawing on survivors' accounts, key informants' assessments, and numerous triangulated indicators, I assess that sexual violence against men in northern Uganda was common and widespread and occurred in many locations across the conflictaffected region. In this context, widespread primarily refers to the spatial extent of these crimes and their frequent occurrence in different places. I mostly utilize the expansive geographical occurrence of these crimes, coupled with respondents' assessments of the pervasive prevalence of sexual violence against men and the invention of the specific vocabulary of tek-gungu to attest this widespread character.

The research underpinning this study has documented the occurrence of maledirected sexual violence in various locations across Acholiland, including in the current-day districts of Gulu, Nwoya, Amuru, Kitgum, and Pader, suggesting that these crimes were geographically widespread. The majority of documented cases are scattered across subcounties and trading centers around Gulu town, the biggest urban center in the region and the epicenter of the conflict (see map 2). At the same time, villages along some of the major and militarily strategic roads connecting Gulu town with other regionally important locations (such as Anaka) or leading north toward southern Sudan (via Pawel or Palaro), where the majority of rebels and former UNLA soldiers were suspected to be in hiding, were particularly affected (see map 3). As indicated by the maps included here-which document the occurrence of male rape-various villages around Alero subcounty on the way to Purongo in the current-day Nwoya district were particularly targeted. Tim Allen observes that in Alero in general, "NRA anti-insurgency measures had been particularly violent" (1991: 375). Other examples are the major routes to Palaro and Awach subcounties, which witnessed widespread sexual violence and the particular targeting of men. Tracing these locations suggests strategic patterns, as expanded upon below, directly corresponding with movements of military operations and the involvement of specific NRA battalions, colloquially referred to as gungu battalions.

Map 2 documents all villages and subcounties across the conflict-affected north where cases of sexual violence against men reportedly occurred. ${ }^{8}$ Due to the 


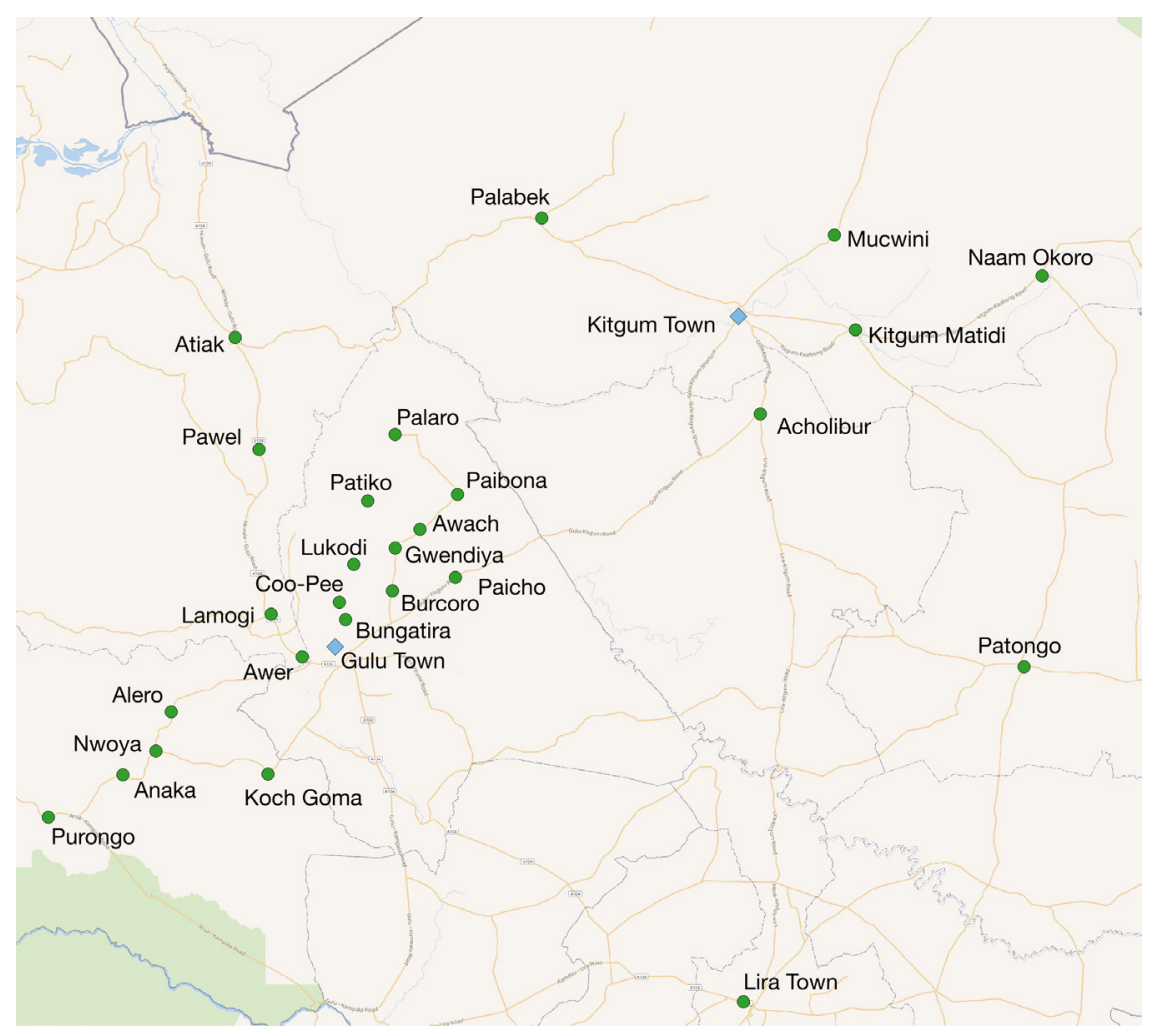

MAP 2. Map of Acholiland documenting cases of tek-gungu.

absence of reliable quantifiable data, the map does not indicate prevalence within respective localities but instead illustrates the variety of locations in which NRA soldiers reportedly raped men.

Map 3 then zooms into specific areas and roads where sexual violence against men was particularly prevalent. Again, this map shows that some of the most important and militarily strategic roads, for instance northward in the direction of southern Sudan or toward Anaka (a traditional opposition stronghold), were especially targeted and affected, corresponding with NRA troop movements and wider conflict dynamics at that time.

Various respondents also referred to the period between the late 1980s and early 1990 , which was characterized by dynamic political developments and intense human rights violations, as the "gungu period." During a focus-group discussion with male elders, one respondent attested that "it was almost only men during that time who were raped-this is why people call it the gungu period." Such illustrative references and connotations suggest that these crimes must have been relatively widespread and/or perceived to be so extraordinary as to make them 


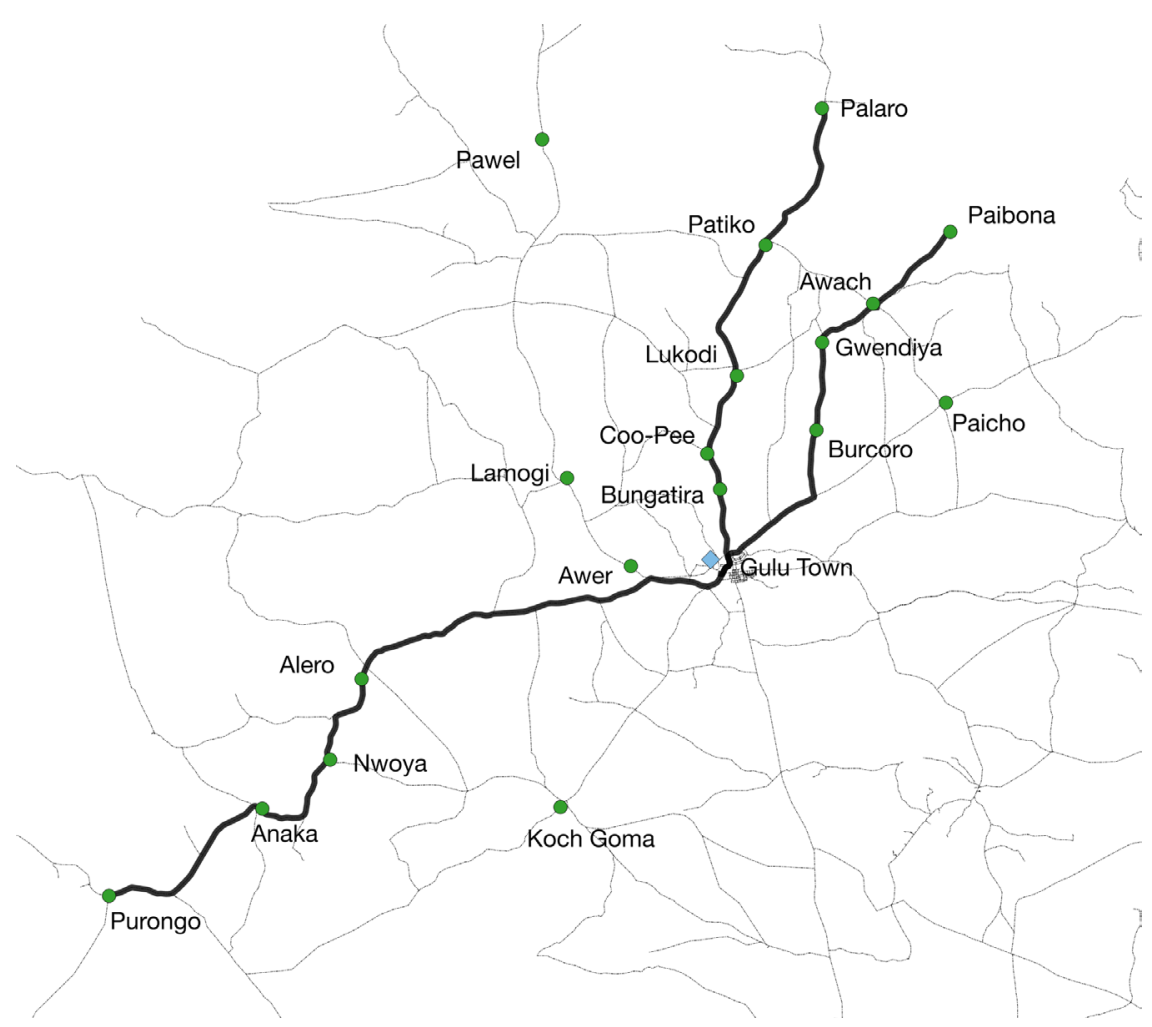

MAP 3. Perpetration of tek-gungu along major and military-strategic roads.

stand out from the extensive catalog of other human rights violations perpetrated by government soldiers during this turbulent period.

Furthermore, compelling evidence exists to suggest that the LRA's top command was well aware of the perpetration of these crimes and used it in its favor politically, in part to mobilize the population against the government. This awareness partly stems from the fact that some of these acts were perpetrated in public and in front of entire communities, as explored further below. Figure 1, from an early rebel manifesto (ca. 1991) that was circulated by the LRA in the early years of their insurgency includes a graphic illustration of an act of tekgungu, showing two clearly marked NRA soldiers raping a man (see Finnström 2009). ${ }^{9}$ The LRA used this to signal and communicate to the Acholi population that Museveni's government was attempting to destroy them, and acts of male rape appeared to constitute a poignant example to demonstrate the NRA's perceived extraordinary cruelty.

Similarly, during the 2006-2008 Juba peace talks, LRA commander Joseph Kony referred to the government soldiers' violent and common practice of raping 


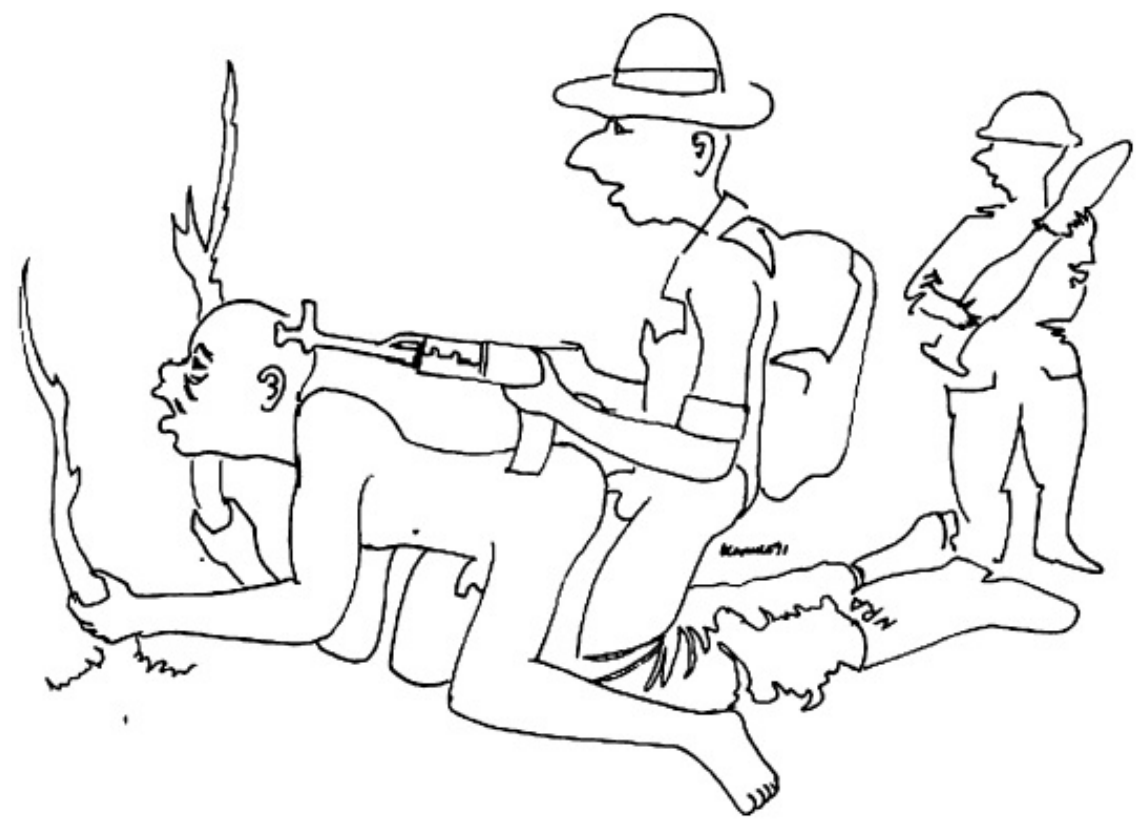

FIGURE 1. Illustration of tek-gungu from Rebel Manifesto (unpublished, untitled, and undated, ca. 1991). (Finnström 2009: 64). Reused with Finnström's approval.

Acholi men. Baines (2014) notes that Kony specifically addressed the peace talks delegation by stating that "the elders should not act like they don't know what caused the war. For instance, in 1990 during Operation North, there were cases in which men who were captured were reportedly sodomized (tek-gungu) by the NRA-don't you know about tek-gungu?" (6).

Overall, the extensive geographical coverage, the communities' statements and assessments, the invention and application of the specific vocabulary of tek-gungu, the gungu period as a time indicator, and the labeling of specific gungu NRA battalions all suggest a widespread occurrence of sexual violence against men by the NRA between the late 1980 os and early 1990s. Some informants, including male survivors themselves, explained that during this period "men were heavily affected by rape." Mirroring the findings presented throughout this section, both Esuruku (2012) and RLP (2014) previously attested that male rape was widespread. The field-based material presented here therefore serves as additional evidence for such prior assessments. While it remains inherently difficult to quantify the extent and scale of tek-gungu, including numbers of victims, the evidence presented here suggests that sexual violence against men within this specific context and during this particular period must have been common and widespread. 


\section{Forms of Male-Directed Sexual Violence in Acholiland}

Forms of sexual violence against men in northern Uganda are quite varied. As conceptualized in chapter 2, I employ a broadened understanding of conflictrelated sexual violence against men, which Carpenter (2006) categorizes into three main types: (1) rape and direct sexual mutilation or torture; (2) civilian men being forced to actively rape or commit sexual violence; and (3) connected harms, referring to situations in which the sexual abuse of women "forms part of a psychological torture against men" (Eriksson Baaz and Stern 2013: 34). Empirical evidence from northern Uganda draws attention to all these forms of sexual violence perpetrated against Acholi men. Male civilians were forcefully raped; men, and in particular youths, in the LRA were forced to have sexual intercourse, either with family members as linked to abduction or in the context of forced marriages; and men were forced to witness their wives, daughters, sisters, or mothers being raped in front of them by either rebels or government soldiers.

While all of these forms of SGBV against men occurred during the conflict in northern Uganda, I specifically focus on penetrative anal rape, perpetrated against civilian men. I employ this focus specifically because male rape was arguably the most common and prevalent form of sexual violence against men during this period in northern Uganda, and certainly the most prevalent form of such violence committed against the vast majority of survivors who participated in this study. Other forms of sexual violence against men-such as genital beatings, stabbings, or sexual humiliations-often accompanied crimes of penetrative anal rape, but mostly did not occur in isolation. Although I am therefore primarily concerned with acts of male rape, the analysis of course also takes into account other sexual violations and harms experienced by the male survivors who participated in this study.

In addition to the vocabulary of tek-gungu, many male survivors commonly described their experiences of sexual violence as butu tek-tek. Interestingly, this is how rape is commonly translated in Acholi and how female victims often refer to their sexual abuse. Porter (2017) writes that this common translation of rape literally means to "sleep strong strong" (223). As argued by Porter, to "sleep with" "is the most common way of referring to having sex in Acholi" (ibid.), and the descriptor tek-tek, "strong strong," refers to the forceful and coercive character of the sexual act. The fact that most male survivors therefore directly refer to their sexual violations as rape, and chose the same terminology as female victims, stands in contrast to some previous studies arguing that men commonly refrain from employing this terminology and instead describe their experiences of sexual abuse as torture without any sexual(ized) specification (see chapter 2).

\section{Localities of Tek-Gungu: Private and Public Spheres}

Crimes of sexual violence against men in northern Uganda occurred within both the private and the public sphere. At times, crimes of male-directed sexual violence 
were perpetrated by "small groups of two to four soldiers in the bushes or even in the men's own homesteads" and therefore in the private sphere, "out of sight of the rest of the community" (JRP 2013: 22, 23). ${ }^{10}$ Various survivors were indeed raped by multiple perpetrators, suggesting a prevalence of gang rape, which across time and space generally constitutes the vast majority of reported wartime rape cases. Cohen notes that "gang rape is a form of public, sexualized violence, which serves to communicate norms of masculinity, virility and strength between fighters of both sexes" (2016: 36).

Other acts of male rape occurred in the public sphere, sometimes in front of the victims' families and communities. For instance, in one subcounty, NRA soldiers separated the men from the women, locked the men into granaries as holding cells, individually singled them out, and then raped them publicly in front of other community members. In other locations, men and women, including husbands and wives, were raped in front of the wider community as a form of public dehumanization and humiliation through sexual violations. One male survivor described that "the rape was done in public, and so many people from here knew about it because they witnessed it." In another instance, as narrated by a survivor: "In the year 1991, government soldiers arrested us. Then they took us and dumped us in the hole in the trading center. The hole was dug by the soldiers and they would use it as a cell. Then in the morning, they would pick us one by one and would tie us on the tree and you were beaten. Then under the tree, there were always spears pointing at you. They beat us seriously, then took us back to the hole and started raping us. We were many, and we were given allegations that we were rebels."

The distinction between public and private spheres matters when seeking to understand male survivors' harms and how they experienced the violations and their aftermath. Specifically, these differing locations shape how the violences are perceived to impact male survivors' masculinities, as different gendered dynamics play out in the private and public sphere respectively, which will be explored more fully in the following chapter. The locations of violence likewise influence survivors' attitudes toward talking about their violations, and their willingness to talk about them, which in turn links to their justice-related concerns and priorities.

\section{Explaining Sexual Violence against Men in Acholiland}

The survivor's narrative above also illustrates that crimes of sexual violence against men during the conflict occurred as integral components of punishment and retaliation attacks against the civilian population at large. Based on these dynamics, below I scrutinize different context-specific explanations for the occurrence of sexual violence against men in northern Uganda, thereby drawing on established theoretical explanatory models introduced in chapter 2.

To fully explain conflict-related sexual violence, however, perpetrator-centric data is needed. Yet, despite a few noteworthy exceptions, there is a persistent lack of data from the perspectives of perpetrators of conflict-related sexual violence. 
For male-directed sexual violence, this lack of perpetrator-centric data is particularly striking, and existing research has not yet explored the motives of these perpetrators. By analyzing patterns of sexual violence against men from a survivors' point of view, we can nevertheless begin to unpack some of the collective dynamics and infer potential causes.

Explanations for conflict-related sexual violence, including against men, are manifold and diverse. As noted in the previous chapter in relation to global dynamics more broadly, conflict-related sexual violence is undoubtedly a complex phenomenon and "any mono-causal theory is unlikely to account for the observed variation" (Wood 2014: 463) in its causes. Most studies suggest that sexual violence against men is primarily strategic and systematic, often portrayed as a weapon of war, aimed at punishing and intimidating its victims, primarily by way of humiliation through gendered subordination and disempowerment.

Although criticism has been directed to the universal framing of sexual violence (primarily against women) as a strategic "weapon of war" (see Eriksson Baaz and Stern 2013), the findings underpinning this study generate convincing empirical evidence to argue that in northern Uganda, sexual violence against men qualifies as a tactic, or at least as a policy, of wider systematic and strategic warfare operations. While I do not necessarily intend to squarely position these crimes within either of these different categories as laid out in chapter 2, as either exclusively opportunism, strategy, or a policy, here I nevertheless tease out the obvious strategic elements and dimensions surrounding these crimes.

Indeed, the geographically widespread acts of tek-gungu perpetrated by the NRA occurred within the context of wider military campaigns and systematic human rights violations against the civilian population at large. As contextualized above, these military operations are locally understood as retaliation and revenge attacks against the Acholis and/or as interrogation and punishment for suspected rebellion or rebel collaboration. A male community member asserted that "the NRA decided to rape men to revenge against the Acholi for what happened in Luwero, and because they accused the population of supporting Kony's rebels." Numerous survivors reported that they were raped on accusation of supporting the LRA or because they were suspected to be former UNLA soldiers. Various survivors were also explicitly accused of "being a father to the rebel" and were told that "this is what you get for supporting Kony." Wood (2014) asserts that sexual violence qualifies as strategic if perpetrated against particular populations and, for instance, "as a form of collective punishment" (472).

Previous research has documented that state armed forces in particular perpetrate sexual violence "where and when rebel forces are visibly active but not strong enough to engage the State in frequent combat, using rape against communities of purported insurgent supporters . . . but also to punish and terrorize [the civilian population]" (Wood 2014: 472). For both Leiby (2009) and Wood (2014), if sexual violence conforms to these dynamics, it qualifies as strategic. These patterns 
certainly apply to general violence, including male rape, perpetrated by the Ugandan state army against Acholi civilian communities as a form of punishment and retaliation. As shown above, many acts of male rape were committed as punishment for accused rebel collaboration. The geographical patterns of the occurrence of tek-gungu, related to military troop movements similarly suggest a widespread and strategic perpetration of male rape (see maps 1 and 2). These crimes also occurred during the early phases of the conflict, when LRA rebel forces were visibly active although not yet strong enough to engage the state army in frequent combat. ${ }^{11}$

Key informants similarly suspected that the "raping of men was a deliberate strategy as part of wider deliberate attempts to discourage and destroy the Acholi, by humiliating and weakening them through rape." Various male survivors stated that during the sexual abuse, the perpetrating soldiers frequently said (mostly in Kiswahili, the lingua franca of the Ugandan army) that they "wanted to finish the Acholi people" or that these acts were intended "as a payback for what happened in Luwero." Most survivors themselves indeed suspected that collective revenge and retaliation as well as the intention to prevent the male Acholi civilian population from rebelling against the government were among the main reasons for the government soldiers to sexually violate them.

As articulated by one survivor, "They chose to sodomize men because men are the ones known to be military strong and they were in the previous government and army. The NRA wanted to show that the Acholi were defeated because they are now weak." A male elder further explained that "men were sodomized and they are now like women because they are also powerless. They targeted men because they were security provider. They were sodomized to prove that they are now powerless." Research by the Justice and Reconciliation Project (JRP) similarly suggests that "the sexual abuse of men was utilized as a way to further humiliate the people .. . by stripping the men of their dignity" (2013: 23) and manhood. The community's interpretations upheld that "men who have been raped are considered to have lost their status as men" (ibid.). Sexual violence therefore is perceived to render Acholi male survivors subordinate to the (non-Acholi) male perpetrators. This gendered devaluation of individual male victims is expected to translate and transfer across the local population more widely. The motive of revenge against and to punish the Acholi, as explored above, therefore played out on a collective and communal level, in a gendered manifestation and with strong ethnicized dimensions.

Another widespread belief regarding the causes of male rape is that these crimes deliberately aimed to infect the Acholis with HIV/AIDS. Olara Otunnu, former undersecretary general of the United Nations and special representative for children and armed conflict and himself a Ugandan, noted that during the conflict "rape and sexual exploitation, especially by government soldiers, have become routine" and "HIV/AIDS is being used as a deliberate weapon of mass destruction" (2009: 1). He further alleged that "government soldiers [were] screened, and those 
who test HIV-positive [were] deployed to the north, with the mission of wreaking maximum havoc. ... Consequently, the rate of HIV infection [in Acholiland] has exploded . . . to staggering levels of 30 to 50 percent" (ibid.). ${ }^{12}$ Behrend (1999) similarly notes that "a high percentage of the soldiers [were] HIV positive," and therefore "many of the rapes result[ed] in infection and thus in death" (183). According to Finnström's (2009) observations, it was locally alleged that the NRA's raping of civilians of both sexes aimed to spread the deadly HIV virus as a way of targeting the Acholi population. Linked to these secondary assessments and speculations, my empirical findings evidence HIV/AIDS infections among the physical consequences of sexual violence against men in northern Uganda (see below). For instance, the data underpinning this study include references to male survivors who died due to HIV/AIDS or who are currently HIV-positive as a result of having been raped by government soldiers. That being said, however, it is of course immensely difficult to verify if the government soldiers purposefully aimed to spread HIV/AIDS among the civilian population, or if this was rather a by-product of these crimes. In light of this, my discussion of these concerns does not intend to agree with or support the claim that male rape purposefully aimed to spread HIV/AIDS among the civilian population.

Taken together, however, all of these intersecting aspects lend strong empirical support for the argument that sexual violence perpetrated by the NRA against the civilian population, including against men, during the northern Ugandan conflict was a deliberate and strategic tactic, conforming with theoretical explanatory models of sexual violence as a strategy, or at least as a policy (see chapter 2). At the same time, however, it remains inherently difficult to verify whether these crimes were specifically ordered by the army's top command, including President Museveni, or whether military orders were issued at lower ranks. As emphasized by Wood, "Organizations that explicitly order combatants to rape are probably rare (but do exist). Probably more common are organizations where some form of sexual violence by combatants is a strategy authorized not by explicit orders but by 'total war' or other permissive rhetoric" (2014: 471, emphasis added).

Various male survivors themselves also suspected that the NRA soldiers specifically chose to rape civilians of both sexes "because they stayed for too long in the bush without seeing their women so they took women and men to have sex with." According to another male survivor, "I think these were soldiers who were so long in the bush without sex so I think this is why they decided to rape me." According to such interpretations, the large-scale occurrence of rape would at least in part be attributed to the fact that, immediately after the guerilla war in central Uganda (1980-86), many NRA soldiers were posted to northern Uganda and thus spent considerable time away from civilian life and their wives or other female sexual partners. Within this context and deprived of sex, NRA soldiers are thought and accused to have raped civilian women and men in order to satisfy their sexual needs. Research by Eriksson Baaz and Stern (2013) demonstrates that many 
people in general, including military staff and soldiers, "understand conflict-related rape in this way" (19).

Such an alternative interpretation would lend empirical support to the opportunistic rape thesis, referring to "rape carried out for private reasons rather than organization objectives" (Wood 2014: 470). Cohen (2016) explains that according to the opportunism argument, which heavily relies on essentialist and dichotomized categories of male perpetrators and female victims, "rape, then, may be the result of a lack of access to sex that would normally take place within combatants' peacetime relationships with their wives and girlfriends" (47). Scholarship on sexual violence against men, however, has almost entirely neglected this explanatory framework. This neglect of opportunism as a potential variable for explaining the occurrence and dynamics of male-directed rape derives from heteronormative and heterosexual assumptions regarding gender relations and the nature of sexual violence.

However, by presenting these survivor viewpoints, I also do not intend to suggest that male rape during the war in northern Uganda should in fact be unitarily qualified as opportunistic violence. To ultimately determine these causes, we must study the perpetrators. At the same time, the evidence too strongly suggests systematic and strategic patterns. The opportunism argument in this context would also downplay the violations' gendered components, and would thus not allow for a sophisticated analysis of sexual violence as sexed and gendered, underpinned by patriarchy and clearly rooted in gender inequalities. Instead, my discussion of these divergent survivors' interpretations aims, first, to contrast male survivors' diverse and individual subjective interpretations regarding the reasons for their sexual violations with conceptually driven scholarly analyses; and second, to underscore that mono-causal explanatory models cannot sufficiently account for the causes of and establish explanations for sexual violence. While the occurrence of male rape in Acholiland thus suggests clear strategic patterns, this does not preclude that individual soldiers at times opportunistically sought sexual satisfaction and gratification out of these acts and that they nevertheless remain closely connected to power. Indeed, "even within the same conflict, sexual violence can serve multiple functions in different contexts and at different points in time" (Leiby 2006: 445) and can have manifold explanations and causes.

\section{CONSEQUENCES OF MALE RAPE \\ IN NORTHERN UGANDA}

Drawing on this wider discussion regarding the dynamics of sexual violence in northern Uganda, it is important to also explore the consequences of such crimes for Acholi survivors, which can broadly be categorized into physical, psychological, and physiological impacts. One male survivor affirmed that "the effects 
of the violations were really many: many health complications, physically and also psychologically."

\section{Physical Consequences}

Various survivors stated that "our biggest challenge is our physical health." Survivors frequently described abdominal pain, waist and back pain, body aches, rectal prolapse and anal ruptures, and anal itching and bleeding, among other symptoms. As a compounded result of many of these health complications, numerous survivors also reported physical difficulties in urinating or passing stool. As described by one survivor, for instance: "I started developing a lot of complications in passing urine and stool with a lot of pain. Every time I go to pass stool, my rectum collapses and at times I discharge blood when passing stool and also when passing urine, I get a lot of pain.”

These medical complications affecting the male survivors reflect the limited existing accounts of physical consequences of sexual violence against men during armed conflict as discussed throughout the literature. ${ }^{13}$ Interestingly, several male survivors related their physical injuries to women's experiences and cataloged the consequences as typically female harms. For instance, one male survivor explained that he "experience[d] waist pain like a woman during pregnancy," while another survivor said he would "always get waist pain which is a thing that happens to women but not to men." Another male survivor described his problems of anal bleeding - a result of rectal prolapse - as "menstruating."

Many of these physical consequences persist into the current postconflict period, up to thirty years after the violations occurred. "I am still feeling the pain up to today," a survivor attested, while another survivor described that "to date, I still have problems; I am still affected up to now." For numerous male survivors, the continuous consequences and harms can be attributed to the lack of medical treatment in the aftermath of the violations. "It was not easy to access medical services in that period of time," a survivor attested. According to yet another survivor, "Unfortunately during that period there was no hospital that was operational here so they were using only warm water to treat me. That is why it has brought me a lot of weakness up to now, because I think that if there would have been an operational hospital that would have been better than now."

While the conflict was ongoing and particularly in the early years of the war, the provision of medical care and the availability of hospitals and health centers were severely limited. Not only male sexual violence survivors, but the entire conflictaffected community with diverse injuries at large was unable to access sufficient medical treatment. The high degree of militarization in the region and insecurities caused by intense rebel activities also prevented civilians in rural areas from traveling longer distances-for instance, to Gulu or Kitgum town, where medical treatment was available, although in a highly restricted capacity. 
At the same time, the situation for male rape survivors was particularly difficult due to fear, shame, and stigmatization underpinned by notions of masculinity and because of health professionals' internalized stereotypes of who can be a victim of sexual violence within a highly heteronormative societal setting. Because of social constructions of Acholi hegemonic masculinity, which disallow men to be vulnerable and dictate that they be strong, the majority of male survivors refrained from reporting their violations and from seeking services, because they were ashamed or because they perceived that "they should be able to cope as men." For instance, an Acholi male survivor described his experience: "I went with the physical complication to [Saint Mary's Hospital] Lacor in 1995. ${ }^{14}$ Reaching Lacor, instead of being seen by a man or at least a mature person, they sent me a young lady to examine me. I refused to undress and went back home so I just bought drugs from the clinic and I have just been taking drugs ever since, but the problem of pain in my anus, waist, and back continues."

Studies across various contexts have previously documented that male survivors face inherent challenges of accessing medical treatment and refrain from reporting the sexual violations committed against them because of these factors. According to another Acholi male survivor, "It was not possible for you to go to the clinic with this violation and explain what happened. They would have laughed at you, called you a homosexual or even reported you to the government." ${ }^{15}$ For feminist scholar Leatherman (2011), this lack of adequate health care and support structures constitutes a clear form of revictimization.

Furthermore, and as described above, the sexual violations often occurred in combination with a variety of other forms of violence, such as torture or severe beatings. The injuries and physical consequences of these (nonsexual) violations frequently intersect with the sexual harms. As a result of these manifold and intersecting physical consequences, various male survivors were unable to work. ${ }^{16} \mathrm{Sev}$ eral male survivors also attested to having been infected with HIV/AIDS as a result of the sexual violations, and participants explained that some former members of their support groups have died as a result of HIV and other sexually transmitted infections and diseases, most probably caused by the sexual violations.

\section{Psychological Consequences}

The psychological consequences experienced by male sexual violence survivors extend from shame, fear, and stigmatization to nightmares, reported symptoms of depression, and social isolation and exclusion as well as feelings of anger and powerlessness, among others.

For one Acholi male survivor, "The immediate impact that the rape brought was fear. I was living under extreme fear that they will come again and either do the same or even do worse." For another male survivor, "Even up to now when I look at a soldier, I start shivering and shaking." According to one survivor, "Because of fear and anger, some victims deliberately joined rebel forces in those early years," 
primarily in an attempt to retaliate against the NRA and to take control (back) into their own hands. Further, according to various survivors, in localities where the sexual violations occurred in the public sphere or where community members otherwise got to know about these crimes, there is "a lot of stigmatization of us by the members of the community and that has really broken our hearts because everywhere we go, people are pointing at us." As narrated by yet another survivor, "From the people here, I feel stigmatization. When people are drunk they will stigmatize me, and that will undermine my dignity as a human being." One male survivor described that he "decided to stay isolated and not in public places, because if I stay with other people there is the problem of stigma. People are calling us the wives of the government or homosexuals because of what happened to us and that is really stigmatizing."

This stigmatization in turn often results in social isolation and exclusion. Because of the humiliation and stigmatization, coupled with fear, various survivors reported that they fled their homes, mostly to Gulu town or other (semi) urban centers across the region. The prevalence of social stigmatization as one central psychological implication of male-directed sexual violence during war and armed conflict has previously been documented in the literature (see Onyango and Hampanda 2011). Most existing studies indeed argue that one of the most common and most severe social consequences for male survivors is the social stigmatization attached to their violations.

Conditioned by a variety of intersecting factors, including shame and social stigmatization, various male survivors were also excluded or expelled from their families and communities, and thus frequently live(d) in isolation. As deconstructed in more depth in the following chapter, a considerable number of male victims were left by their wives or wider families due to the stigma attached to the sexual violations committed against them. Comparable to the absence of medical treatment, there similarly was a striking lack of psychosocial support, further exacerbating survivors' psychological problems. For instance, one male survivor said, "Psychologically, we were also greatly affected because of many troubling thoughts but we had nobody to share our experiences with and get any emotional support." ${ }^{17}$

\section{Physiological Consequences}

The majority of male survivors moreover reported physiologically conditioned inabilities to achieve or sustain an erection and attributed this to their sexual violations. "Ever since the rape, I cannot get an erection anymore," one male survivor attested. As Edström, Dolan et al. (2016) point out, "One of the most common physiological dimensions of the impact on male victims of sexual violence appears to be its almost universal numbing of their capacity for sexual arousal. An inability to achieve or maintain erections-so central to their relations with their wives or female partners-is the visible symptom" (26). 
"My desire for sex vanished and diminished ever since the rape," one survivor similarly described. Research on male-directed sexual violence outside the context of war-for instance, in prison settings, male fraternities, or the militarydocuments similar effects on male survivors' desire for sexual intercourse or on their physiological abilities to achieve an erection. Specifically focusing on sexual violence against men within the setting of war and armed conflict, only few existing studies have paid particular attention to these physiological consequences, including their gendered implications. ${ }^{18}$ Against this background, in the following chapter, I more closely examine how the inability to erect, to have sex, and thus to procreate-which is so central to the Acholi model of hegemonic masculinityimpacts male survivors' gendered identities.

\section{SEXUAL AND GENDER-BASED VIOLENCE AGAINST WOMEN AND GIRLS IN NORTHERN UGANDA}

Crimes of sexual violence against men must also be positioned in relation to other forms of sexual and gender-based violence perpetrated during the conflict more broadly. Okello and Hovil (2007) note that gender-related crimes during the conflict have been pervasive, while Finnström (2009) similarly observes that during the course of the conflict, "sexual violence and rape have . . become common in war-torn northern Uganda" (63). From the early to mid-199os, crimes of sexual violence were primarily directed against civilian women perpetrated by government soldiers, LRA rebels, and civilian men alike (Baines 2014; Porter 2017).

The breakdown of social relations (Porter 2016), catalyzed by the conflict in general and the massive forced displacement in particular, contributed to growing rates of domestic violence and spousal abuse. Sexual and gender-based crimes committed by civilian men against their partners or against other women are often linked to changing gendered power relations. Okello and Hovil (2007) observe in this regard that in the camps "men, unable to support their families, feel impotent, which leads them into a vicious cycle of anger and abuse" (442). Because women often became the main recipients of aid distributions within the camps and were thus (temporarily) the main provider for their families, men's identities and roles as household heads were threatened, producing a context in which some men reverted to (sexual) violence to (re)gain power and dominance and (re)assert their masculinities. Further, high insecurities, constrained income-generating activities, and inhumane living conditions in the camps often left women dependent on "survival sex" in exchange for food or security, often offered by the soldiers stationed within the camps.

Women and girls abducted by the LRA were also subjected to various forms of sexual and gender-based violence. Although a strict sexual conduct prevailed within the LRA, young female recruits were given as servants and wives to male commanders within the context of "forced marriages", and senior commanders 
often had several wives (Baines 2014). Some men-especially younger, less senior recruits or abductees-were also forced into these marriage arrangements, which can therefore also be seen as a form of gender-based violence against men in a broadened conception, although this constitutes a subject of further study. Based on statements by Joseph Kony and other top LRA commanders, Baines (2014) considers forced marriages to be a component of the LRA's political project of imagining a new Acholi national, by way of "reproducing-literally giving birth to-the [new] nation" (2). Baines therefore explains that "the vision of the "new Acholi' was operationalized through the institution of forced marriage and recreation of the familial unit" (6).

Within the rebel ranks, sexual relations outside the context of these arranged marriages were strongly prohibited, and violations of these rules, including the rape of civilians or (forced) sex with other LRA abductees, were punished, often in the form of severe beatings or death (Amony 2015). Baines (2014) quotes a former female abductee who explains that "the rape of civilians did not happen. There was a rule among the Holy (the LRA) that no one was to be promiscuous. This meant that when you abducted a civilian you were not to sleep with her recklessly" (8). As explained by Baines (2014), such rules primarily aimed to protect "the moral purity of the new Acholi as a chosen group" (6). Despite these regulations, however, there clearly were cases of sexual violence against civilian women by the LRA. Based upon research with 187 female rape survivors in Gulu district, Holly Porter (2013) notes several incidents of female civilian rape by the LRA. Baines in her research furthermore "encountered dozens more incidents" (2014: 8). According to Baines, "The LRA undoubtedly carried out civilian rape even if reported in smaller numbers, but likely these were incidents that took place without the knowledge of more senior commanders" (ibid.), thus suggesting opportunistic causes.

At the same time, many former LRA "bush wives" continue to face numerous gendered challenges and experience diverse forms of sexual and gender-based violence and discrimination upon return to civilian life. For instance, returnees are often exposed to violence by family or community members and experience highly gendered discrimination in terms of limited access to education, income-generating activities, or, crucially, agricultural land for themselves and their children. In the sociocultural context of Acholiland, children born of war face additional hardship. For instance, they often do not have a relationship to their paternal clans. This is especially problematic, as in Acholi's patrilineal and patrilocal culture, a child's identity is linked to his or her father's family and clan. Knowing one's paternal home village is a paramount aspect of social belonging and identity formation.

\section{Sexual Violence against Men within the LRA}

Although the overwhelming majority of sexual violence crimes against men in northern Uganda were committed by government soldiers, and most forms of sexualized and gender-based crimes perpetrated by the LRA targeted women, a 
few isolated cases of male-directed sexual violence by the LRA exist. While studies on NRA-perpetrated sexual violence against men are generally scarce, research on such violence within and by the LRA thus far remains almost nonexistent.

My research, in the form of coincidental findings, has uncovered at least two cases of male-on-male rape within the LRA. In both cases, senior male commanders raped young male LRA recruits, and the dynamics of these instances suggest opportunistic motives rather than strategic causes. While "sexually immoral behavior" (Baines 2014: 1) in the form of sexual violence against women was prohibited and often punished by severe beatings, the former forced wife of a rebel commander explained to me that the rape of men within the LRA was "considered unimaginable" and indeed punishable by death. This harsh punishment of male sexual abuse within the LRA may be linked to the group's and Kony's spiritual beliefs and their heteronormative (and homophobic) conception of family and society. In one of these reported cases, the commander, who also had several forced wives, was shot immediately when the LRA leadership found out he had sexually abused a male recruit. In another instance, the sexual abuse stopped when the victimized abductee threatened to report the commander to the LRA leadership, which inevitably would have resulted in the commander's execution. In addition to these sporadic cases of male-on-male rape, a group of counselors of a psychological-support service provider working with former LRA abductees similarly reported a rare instance of continuous sexual abuse of a young male recruit by a senior female commander. These few isolated reported cases of male-directed sexual violence are likely not the only instances of sexual violence against men within the LRA, and hence warrant further research.

\section{CONCLUSION}

In this chapter I have painted a detailed picture of the extent and dynamics of sexual violence against men during the conflict in northern Uganda, situated within wider conflict dynamics and in relation to gendered forms of violence more broadly. This chapter thereby provides the contextual groundwork for the analysis in the following chapters.

Based on original empirical field research findings, I demonstrated that crimes of sexual violence against men committed by government soldiers of the NRA between the late 1980 s and early 1990 s against Acholi civilian men were geographically widespread, resulting in the application of the new vocabulary of tek-gungu. I have shown that sexual violence against men in Acholiland, situated in relation to wider conflict dynamics, suggests clear strategic motives and rationales behind the perpetration of these crimes.

While this chapter already included an exploration of the gendered and sexual manifestations and consequences of male rape, a sustained, empirically driven yet 
theoretically grounded understanding of how sexual violence against men compromises male survivors' gendered identities remains thus far only insufficiently explored. Against this background, the following chapter proceeds by unpacking how sexual violence against men impacts male survivors' masculinities to aid our understanding of the gendered harms experienced by survivors. 